\title{
Selection of Grass and Broadleaf Crops as Catch Crops where Winery Wastewater is Used for Irrigation: A Review
}

\author{
J.C. Fourie, C.L. Howell", N. Masekwana \\ ARC Infruitec-Nietvoorbij, Private Bag X5026, 7599, Stellenbosch, South Africa
}

Submitted for publication: June 2020

Accepted for publication: December 2020

Key words: Cellar effluent, chemical oxygen demand, forage land, interception crops, potassium, sodium

\begin{abstract}
Winery wastewater contains high levels of elements such as sodium, phosphorus, potassium, as well as chemical oxygen demand, sodium adsorption ratio and $\mathrm{pH}$. This may raise concerns regarding the pollution of the surrounding environment. Environmentally friendly methods such as recycling, i.e. treatment and re-use, where treated or partially treated and diluted wastewater is used for irrigation of agricultural crops, are essential. Irrigation with winery wastewater, which is rich in nutrients, can be beneficial to overall soil fertility as an alternative to conventional fertilizers. However, long-term applications of wastewater may have a negative effect on soil physicochemical properties. A selection of crops with nutrient interception abilities, preferably for salts, may be ideal for the removal of excess elements from the soil whilst reducing leaching and excess run off. The use of perennial grasses, annual winter growing grains and winter growing broadleaf nitrogen-fixing annuals as winter cover crops in the South African wine industry has been extensively documented but their use as summer catch crops intercepting elements applied via wastewater irrigation has not yet been well researched.
\end{abstract}

\section{INTRODUCTION}

Winery waste production: A South African perspective Increased wine production in South Africa has elevated the pressure of the wine industry on natural resources such as water, soil and vegetation, including through the production of winery wastewater (Mulidzi et al., 2016). Local wine cellars are estimated to generate between 2190 million and 15330 million L of wastewater per annum (Fourie et al., 2015). Winery wastewater is regarded as the most significant environmental risk at wineries (Van Schoor, 2000).

\section{Winery wastewater composition}

Winery wastewater contains high levels of elements such as potassium $(\mathrm{K})$, sodium $(\mathrm{Na})$ and phosphorous $(\mathrm{P})$ (Laurenson \& Houlbrooke, 2011; Sheridan et al., 2011; Conradie et al., 2013). It can also have a high chemical oxygen demand (COD), sodium adsorption ratio (SAR) and $\mathrm{pH}$, which may raise concerns about the pollution of the surrounding environment, especially if the wastewater is not treated correctly (Conradie et al., 2013). Wastewater can also have a high organic content, low $\mathrm{pH}$ as well as variable salinity and nutrient levels, all of which indicate that the wastewater has the potential to pose an environmental threat (Mosse et al., 2011; Laurenson et al., 2012).

Wastewater management in wineries

Revised general authorizations promulgated in 2013 (DWA,
2013) stipulate that the disposal of wastewater should be subjected to the requirements of the National Water Act (1998). This means that winery wastewater cannot be discharged into natural water sources without extensive treatment. The legislation allows for disposal via irrigation if there is continuous monitoring of the wastewater quality (Sheridan et al., 2011). Approximately 95\% of South African wineries would either irrigate winery wastewater onto pastures, place it in evaporation dams or drain it into the nearest river after treatment (Van Schoor \& Rossouw, 2004). The use of treated or partially treated effluent for irrigation of agricultural crops is an alternative to discharging it into fresh water ecosystems (Mulidzi, 2001; Van Schoor, 2005). However, long-term application may alter the physicochemical properties of the soil (Arienzo et al., 2009), and should therefore be monitored.

\section{EFFECTS OF WINERY WASTEWATER ON SOIL AND CROPS}

Effect of winery wastewater on soil

The negative impacts associated with untreated wastewater used for irrigation are well documented (Mulidzi, 2001; Laurenson et al., 2012; Mulidzi et al., 2016). The risk of direct contamination of the soil associated with wastewater application is dependent on the transport mechanism of water and, therefore, solutes and suspended solids in the

\footnotetext{
*Corresponding author: E-mail address: howellc@arc.agric.za

Acknowledgements: This literature review paper forms part of Project P04000027 funded by Winetech and the Agricultural Research Council (ARC). The research project is entitled "Evaluation of selected grass and broadleaf crops suitable for fodder as catch crops where winery wastewater is re-used for irrigation.
} 
water. A high COD is indicative of a high pollution level, which inevitably results in a depletion of water or soil oxygen that leads to, among others, root growth inhibition and the potential production of malodorous compounds (Van Schoor, 2005). Where four differently textured clay soils were irrigated with winery wastewater diluted to 3000 $\mathrm{mg} / \mathrm{L}$ COD, soils with a clay content of $20 \%$ showed an increase in $\mathrm{K}$ compared to the soils with less than $13 \%$ clay (Mulidzi et al., 2016). Similarly, soils with a higher clay content tended to retain a higher amount of exchangeable $\mathrm{K}$ than soils with a lower clay content after irrigation with winery wastewater (Arienzo et al., 2009). There was an increase in soil $\mathrm{pH}_{(\mathrm{KCl})}$ for all four soils, irrespective of clay content (Mulidzi et al., 2016). The increase in soil $\mathrm{pH}_{(\mathrm{KCl})}$ was attributed to the addition of bicarbonate salts and other organic anions, which entered the soil via irrigation with diluted winery wastewater.

High levels of $\mathrm{Na}$ present in winery wastewater affects the permeability of soil and may cause infiltration problems (Van Schoor, 2001). This is due to $\mathrm{Na}$, present in an exchangeable form in the soil, replacing calcium $(\mathrm{Ca})$ and magnesium $(\mathrm{Mg})$ on the soil clays, thereby causing dispersion of particles. This affects the soil structure, reducing soil macro-porosity, soil aeration, available soil water and results in a reduction in soil permeability. Additional problems that crops may experience due to an excess of $\mathrm{Na}$ include, but are not limited to, the formation of crusting seed beds, temporary saturation of the surface soil and high $\mathrm{pH}$ (Van Schoor, 2005). Exchangeable $\mathrm{Na}$ in heavier soils was double that of sandy soils where four differently textured soils were irrigated with winery water diluted to $3000 \mathrm{mg} / \mathrm{L}$ COD (Mulidzi et al., 2016). This reaffirmed the knowledge that $\mathrm{Na}$ accumulation will be less in sandy soils.

Soils with $\mathrm{pH}_{(\mathrm{KCl})}$ less than 6 should have exchangeable $\mathrm{K}$ $\left(\mathrm{K}_{\mathrm{ex}}\right)$ saturation of $4 \%$ to maintain optimal grapevine growth (Conradie, 1994). Furthermore, soils with $\mathrm{K}_{\mathrm{ex}}$ above $4 \%$ are more likely to accumulate $\mathrm{K}$, resulting in poor wine colour. Irrigating soils with K-rich wastewater may be beneficial to those soils that have a low K concentration, as this can be an alternative to conventional fertilizers (Myburgh \& Howell, 2014a). Although the addition of K may improve overall soil fertility, continuous application of K-based wastewater to soils displaying elevated $\mathrm{K}$ levels (prior to irrigation with wastewater) may be negative, as long-term application may alter the physiochemical properties of the soil (Arienzo et al., 2009).

There are three primary mechanisms for the transport of water (containing solutes \& suspended solids) through the soil, namely matrix flow, preferential flow and overland flow (Houlbrooke et al., 2011). Preferential and overland flows provide little soil contact time and thus minimal opportunity for the attenuation of applied contaminants such as nitrogen (N) and $\mathrm{P}$. Ammonia $\left(\mathrm{NH}_{3}\right), \mathrm{Ca}, \mathrm{Mg}$ and $\mathrm{K}$ are soil elements essential to plant growth, whereas $\mathrm{Na}$, aluminium (Al) and hydrogen $(\mathrm{H})$ are not essential for plant growth, but have an effect on soil pH (McClellan et al., 2009). Roots should be in contact with nutrients in the soil for nutrient uptake to occur (Wang et al., 2006) and this can occur in three ways, namely root interception, mass flow and diffusion. In root interception, there is physical contact between the nutrient and root surfaces, therefore nutrient uptake will increase with an increase in root surface area and mass. In mass flow, nutrients are transported by the movement of water in soil and this is therefore affected by water flow rate. Therefore there will be a decrease in mass flow when the soil becomes drier. In diffusion, there is a movement of nutrients across a concentration gradient and this process depends on the concentration of the nutrients in soil solution.

\section{Effect of winery wastewater on crops}

Phytoremediation is a technology that utilizes higher plants for the clean-up of contaminated environments (Paz-Alberto \& Sigua, 2013) such as soils, water or air. Desirable characteristics for these plant species are fast growth, high biomass, extended root system for exploring large soil volumes, high tolerance to metal in plant tissue, high translocation factor, the ability to adapt to specific environments and easy management (Paz-Alberto \& Sigua, 2013). Previous studies with winery wastewater treatment systems have included the removal of nutrients by plants like kikuyu (Pennisetum purpureum), lucerne (Medicago sativa) and flanker grass/Italian ryegrass (Lolium multiforum), saltbush (Atriplex spp), wetland plants and certain cover crops (Zingelwa, 2004; Zingelwa \& Wooldridge, 2009; Zingelwa \& Wooldridge, 2010). Due to the interception ability of some cover crops, they may also be ideal for the removal of excess nutrients from the soil, whilst reducing leaching and excess run-off (Fourie et al., 2015).

According to Pederson et al. (2002), Avena sativa L. (oats) has the potential to be used as a catch crop, with hay production and sale off-farm as a viable method for removing excess nutrients. Pennisetum glaucum L. (pearl millet) is also widely used as fodder in developing countries and is a summer crop that requires little irrigation due to a short growing season (Blümmel et al., 2003; Khan et al., 2012). Pearl millet, which is considered to be fairly saline tolerant (Krishnamurthy et al., 2007), has reduced $\mathrm{N}$ content in the shoots and an increase in the $\mathrm{K}$ and $\mathrm{Na}$ content under saline conditions (Fourie et al., 2015 and references therein). The negative effect of high levels of $\mathrm{Na}$ in irrigation water on the growth of pearl millet could be restored partially (Albassam, 2001 ) by the application of $\mathrm{N}$ as cover crops have the ability to add or conserve soil N (Fourie et al., 2007a; Fourie et al., 2007b; Fourie, 2012; Aronsson et al., 2015; Aronsson et al., 2016).

\section{COVER CROP SELECTION}

\section{Factors to consider when selecting cover crops as catch crops}

In agriculture, a catch crop is defined as a crop that is grown between successive plantings of a main crop. For example, in the case of vineyards, the grapevines would be the main crop. Cover or catch crops are used for reducing nutrient leaching, transferring $\mathrm{N}$ to the next main crop, increasing biodiversity and maintaining or improving soil structure (Peltonen-Sainio et al., 2014). Catch crops are popular in forage studies. Catch crops should be able to be used as fodder crops in grazing lands (Meisinger et al., 1991). If these catch crops are harvested for fodder, they can be considered as another production system and therefore the related burdens are 
charged to the harvested fodder (Nemecek \& Galliard, 2010).

Due to the current water scarcity in South Africa, using winery wastewater for irrigation of fodder producing annuals in vineyards and on open land could be economically viable to producers. However, it is not known whether this would be possible without compromising the environment (Tesfamariam et al., 2013). In a field study where Pennisetum glaucum L. cv. Babala (Pearl millet) and Avena sativa cv. Pallinup (Pallinup oats) were used as catch crops in a vineyard irrigated with diluted winery wastewater, pearl millet intercepted substantial amounts of $\mathrm{K}$ (Fourie et al., 2015). This is also attributed to the vigorous growth of the crop. Amounts of $\mathrm{Na}$ taken up by the pearl millet were low. Using pearl millet and Pallinup oats to intercept the elements deposited via the diluted winery wastewater resulted in more $\mathrm{N}, \mathrm{K}, \mathrm{P}, \mathrm{Mg}$ and $\mathrm{Ca}$ being removed from the soil than was applied by means of the wastewater and fertiliser. Certain cover crops flourish under these conditions, finding the effluent water to be a rich source of nutrients (Karpiscak et al., 1996). Therefore, different catch crops and catch crop/cover crop combinations need to be evaluated to determine which would be best at intercepting $\mathrm{K}$ and $\mathrm{Na}$, whilst improving the $\mathrm{N}$ deficit created in the process.

The use of perennial grasses, annual winter growing grains and winter growing broadleaf $\mathrm{N}$-fixing annuals as cover crops as an effective vineyard floor management practice has been well documented in the wine producing areas of South Africa (Fourie et al., 2001; Fourie et al., 2005; Fourie et al., 2006; Fourie et al. 2007a; Fourie, 2011). Cover crops improve grapevine performance compared to other soil management practices (Fourie et al., 2006; Fourie et al., 2007c; Fourie, 2011). Due to the interception ability of certain winter growing annual cover crops, such as Pallinup oats (Fourie et al., 2015), cover crops could be utilized in a cropping system to absorb and recycle soil nutrients such as K.

\section{Annual grasses \\ Pennisetum glaucum (Pearl millet)}

Pearl millet is a tall, warm season annual grass belonging to the family Poaceae. Production of pearl millet by smallholder farmers is still at subsistence level and it is consumed as a staple food or processed into a beverage in most areas. It has gained ground as a competitive forage crop by commercial dairy farmers (Abd El-Lattief, 2011). There are no available records with regard to the size of land currently under production and the quantities produced in South Africa, although it is also grown commercially (DAFF, 2011).

As an annual, it has a short growing season and therefore does not require a lot of irrigation, making it an important summer cereal crop in a developing country such as South Africa (Blümmel et al., 2003; Khan et al., 2012). Pearl millet thrives in well-drained loam soils. However, its performance is diminished in clay soils and it can't tolerate waterlogged environments. Pearl millet uses relatively low amounts of water per unit of forage production and tolerates both lower and higher soil $\mathrm{pH}$ (Harinayarana et al., 2005). As a fodder crop with an average production of 433 bales per hectare when irrigated with winery wastewater, pearl millet has the potential to generate an income of R45 per bale, which would amount to R19 485 per ha under the prevailing conditions (Fourie et al., 2015). A pearl millet catch crop in summer, followed by Pallinup oats in winter in a vineyard near Rawsonville resulted in additional $\mathrm{N}, \mathrm{P}, \mathrm{K}, \mathrm{Mg}$ and $\mathrm{Ca}$ being removed from the soil, whereas the concentrations of $\mathrm{Na}$ removed, remained negligible. Similarly, effluent was used efficiently for the commercial production of pearl millet, where effluent irrigation improved plant growth and yield (Khan et al., 2012).

Pearl millet irrigated with winery wastewater diluted to a COD level of 1500 to $2500 \mathrm{mg} / \mathrm{L}$ could be a sustainable fodder crop, as the diluted winery wastewater did not affect the above-ground N, P, Ca and Mg concentrations (Myburgh \& Howell, 2014a). Wine quality was also not affected. It should be noted that in this particular trial, only pearl millet was investigated as a potential catch crop to intercept the salts applied via irrigation with diluted winery wastewater. For maximum phyto-extraction potential to be obtained, pearl millet should be sown in a vineyard as a catch crop in early January to reach the two to six leaf stages when winery wastewater would be applied and to ensure that it does not complete its life cycle too early (Fourie et al., 2015). Millet is generally considered as fairly tolerant to salinity, could be an alternative crop option for salt affected areas and has been found to be a suitable crop to grow while salt leaching is occurring (Oleiwi et al., 2015).

\section{Sorghum bicolor (L.) Moench (Barsweet sorghum)}

Sorghum is the fifth most important cereal crop in the world after rice, wheat, corn and barley (Wiersema \& Dahlberg, 2007). In addition to its use for syrup production in America, it also has the potential of being a viable bio-ethanol feedstock. The morphological characteristics of the species make it one of the currently cultivated cereals with the best drought tolerance (Ramatoulaye et al., 2016). Sweet sorghum grows well in a variety of climates, including those where the soil is of a poor quality. However, cultivation peaks in the semiarid tropics, where poor soils, low and variable rainfall and economic constraints dominate.

Nutrient removal rates of barsweet sorghum remains scant. Ketterings et al. (2006) reported on the nutrient uptake of Brown Midrib Sorghum Sudan grass and the relationship between dry matter production (DMP) and nutrient removal rates. The study revealed that $80-95 \%$ of $\mathrm{K}$ removal was attributed to the DMP, implying that DMP can be used as an indicator for nutrient removal. The observed increase in DMP was positively correlated with nutrient removal for sorghum. The crop removed substantial amounts of $\mathrm{P}$ and $\mathrm{K}$ in manured sites suggesting that it could be used as an effective accumulator of excess nutrients, common in winery wastewater.

\section{Eragrostis teff (Zucc.) Trotter (Teff)}

Teff is a self-pollinating, gluten-free cereal, indigenous to Ethiopia where approximately 14 million ha produces around 0.9 million tons of grain. Teff is a highly palatable and nutritious fine stemmed hay which can be cultivated as a forage crop for both cattle and horses (Davison et al., 2011). As such, in South Africa, it has been exclusively produced for hay (Kassier, 2002). More recently, dairy farmers have 
started using it as a grazing pasture for the late summer and early autumn period. Teff is a viable drought tolerant forage crop and can be cultivated in areas with varying climatic conditions (Seyfu, 1993; Davison et al., 2011). However, it performs better in warmer climates with maximum growth experienced during hot days and warm nights, and has a relatively short growth period of 40 to 60 days during summer. Compared to other cereals, teff is more tolerant of extreme environmental conditions especially waterlogging and is unique in its ability to grow and produce a yield on poorly drained soils which most cereals can't tolerate (Assefa et al., 2011; Assefa et al., 2015). As a fodder crop, it fills a niche for producers seeking an annual summer crop with a short growing time (Stallknecht et al., 1993; Davison et al., 2011).

Research has indicated that various factors contribute to successful yield of teff, and these include, but are not limited to: irrigation levels, fertilizer application and the variety (Kebede, 2012). A study of 15 lowland Teff genotypes (10 accessions \& five varieties) grown at different $\mathrm{NaCl}$ sodicity levels showed that a salinity level of $2 \mathrm{dS} / \mathrm{m}$ enhanced growth with respect to the above-ground dry weight per plant, root dry weight per plant and total dry weight per plant in some accessions and varieties when compared to the control (Asfaw \& Dano, 2011). However, at $16 \mathrm{dS} / \mathrm{m}$, which was the highest level of salinity tested, all accessions and varieties were negatively affected, with the varieties being more salt sensitive than the accessions.

\section{Perennial grasses}

Eragrostis curvula (Weeping lovegrass)

Weeping lovegrass is mainly used for pastures or hay (FAO, 2011), but is also used in leys with alfalfa crops, in drier farming areas, and as a cover crop to protect soil from erosion (Cook et al., 2005). Weeping lovegrass is well adapted to a variety of soil and climatic conditions. This species survives receiving as little as $450 \mathrm{~mm}$ of rain annually, however it is mainly grown in regions receiving $650 \mathrm{~mm}$ rainfall or higher annually (Cook et al., 2005). Although it is adapted to low $\mathrm{pH}$ soils, soil pH of 6 to 7 is more ideal, and this can be achieved through lime application with $\mathrm{P}$ at $15-20 \mathrm{mg} / \mathrm{kg}$ prior to establishment, while soil $\mathrm{K}$ should remain between 100 and $150 \mathrm{mg} / \mathrm{kg}$ (Cook et al., 2005). Yields of 4-13 t/ha can be expected if regular irrigation is applied or rainfall occurs. Weeping lovegrass is one of the highest producing grasses in the summer rainfall areas of temperate and cool subtropical areas of South Africa (Strickland, 1973). Squires and Myers (1970) reported superior DMP for animal production when compared to other perennial grasses. There were high levels of $\mathrm{Na}$ accumulation by E. curvula when it was irrigated with sodium sulphate rich mine effluent (Beletse, 2004). Due to the plant's ability to absorb substantial amounts of $\mathrm{Na}$ from the soil, it may have potential to be considered as a catch crop for the removal of excess $\mathrm{Na}$ from soils irrigated with winery wastewater.

\section{Vetiveria zizanioides (Vetiver grass)}

Vetiver grass, which is the foundation of the Vetiver System (VS) (Truong et al., 2002; Truong et al., 2003), was first developed for the conservation of soil and water in India in the 1980s by the World Bank. It has unique morphological, physiological and ecological characteristics which have allowed this perennial grass to adapt to a wide range of climatic and soil conditions, as well as salt affected land (Truong et al., 2002; Danh et al., 2009). Morphological characteristics, such as a strong and extensive root system (descending approximately 2-3 $\mathrm{m}$ in the first year), provide the plant with a great tolerance to drought and allows for infiltration of soil water. Under certain Australian conditions, vetiver grass displayed tolerance to high soil salinity and compared favourably with some of the most robust salt tolerant crop and fodder species (Truong et al., 2002). In a study where growth yield of ten perennial grasses were compared, vetiver grass produced the third highest dry leaf weight and dry stem weight, under rain fed conditions (Anwar et al., 1996). Zingelwa and Wooldridge (2010) reported no visible signs of physiological stress at $\mathrm{Na}$ concentrations ranging between 0 and $400 \mu \mathrm{M}$ Na per $\mathrm{L}$ at $20000 \mathrm{mg} / \mathrm{L} \mathrm{COD}$. As vetiver grass displays tolerance to saline environments and elevated $\mathrm{Na}$ according to Truong (1994), it is a promising catch crop for the removal of excess nutrients. It can also be used as a fodder crop for livestock, as it is highly digestible and palatable to horses, dairy cows, cattle, buffalo, rabbit, goats and sheep (Truong et al., 2002).

\section{Anthephora pubescens (Bottlebrush grass)}

Bottlebrush grass is a tufted grass which has a single ear inflorescence on the tillers, which can grow between 400 and $1200 \mathrm{~mm}$ long (Strohbach, 2000; DAFF, 2012). This species is found throughout South Africa on sandy soils and may be found on soils with high clay content. Optimum production is achieved at a neutral $\mathrm{pH}$ of 6.5 . Bottlebrush grass is found naturally in arid areas and regions experiencing rainfall between 250 and $650 \mathrm{~mm}$ annually. Bottlebrush grass can be grown in soils with a low $\mathrm{P}$ content as it is adapted to low P soils. However, it is recommended that $150-200 \mathrm{~kg} /$ ha of superphosphate be applied prior to establishment for increased yields and a soil P content of no less than $12 \mathrm{mg} /$ $\mathrm{kg}$ be maintained (Grain SA, 2014). Due to its palatability, it may be used for both summer and winter grazing and has proved successful as a forage crop in the Northern Cape.

\section{Annual broadleaf crops}

Raphanus sativus (Fodder radish)

Fodder radish is often used as a cover crop because it contributes to the maintenance of cropland soil fertility and productivity by alleviating soil compaction, reducing $\mathrm{NO}_{3}$ leaching, suppressing weeds and controlling erosion. Fodder radish as forage is high yielding, producing high quality and easily digestible fodder material (Ngouajio \& Mutch, 2004). Fodder radish is unique in that it has a relatively high tissue $\mathrm{P}$ concentration. It rapidly produces dry matter followed by swift decomposition (White \& Weil, 2011). Fodder radish can be identified by its large fleshy taproot, which is approximately $3-6 \mathrm{~cm}$ in diameter and $15-30 \mathrm{~cm}$ in length. During winter, the taproot decomposes leaving distinct holes approximately 3-6 cm in diameter and 5-10 cm deep in the soil surface, which may may promote water infiltration and reduce run-off (White \& Weil, 2011). Additionally, this deep rooting system aids in addressing an array of cropland 
concerns, inter alia; soil compaction as the thick taproot is capable of penetrating compacted soil layers (Williams $\&$ Weil, 2004). Since fodder radish develops a deep root system, it depletes $\mathrm{N}$ from deeper soil layers (Kristensen \& Thorup-Kristensen, 2004; Sapkota et al., 2011). The $\mathrm{N}$ is released into the soil when the plant decomposes (Kristensen \& Thorup-Kristensen, 2004). According to Glabb and Kullkig (2008), fodder radish is widely used as a catch crop. This Brassicaceae species plays an important role in limiting $\mathrm{N}$ leaching losses in the $0-90 \mathrm{~cm}$ soil layer and also increases organic $\mathrm{C}$ content.

Fodder beets are members of the amaranth and goosefoot family (Amaranthaceae), whereas radishes are members of the brassica family. Recently, research showed that potted fodder beet grown during summer in sandy soil absorbed 38\% of $\mathrm{Na}$ applied via $\mathrm{Na}$-enriched irrigation water (Myburgh \& Howell, 2014b). The concentration of Na applied was equal to that of the Na concentration in the irrigation water of the $3000 \mathrm{mg} / \mathrm{L}$ COD treatment in a field trial. Furthermore, the fodder beet reduced $\mathrm{K}_{\mathrm{ex}}$ by $50 \%$, indicating that it could also absorb K applied via winery wastewater. Taking the abovementioned into consideration, the use of fodder radish and beet as catch crops where excess $\mathrm{Na}$ is applied via wastewater application could be viable.

\section{Perennial broadleaf}

\section{Cichorium intybus (Chicory-commander)}

Chicory is a perennial, blue-flowered plant of the Asteraceae family, with large, fleshy taproots (Philips, 2017). It is a warm season herbaceous plant with an upright and spreading vine type architecture (Anon, 2015). "Commander", which is a forage type, is a winter active chicory, providing great year round growth, improved root rot resistance and excellent grazing (Anon, 2017). Chicory is a persistent leafy herb, lasting 2-3 years with a large tap root. It performs best in fertile, free draining soils in regions where the annual rainfall is higher than $550 \mathrm{~mm}$. The crop has a high $\mathrm{N}$ requirements and prefers soil $\mathrm{pH}$ above 5.5 (Kammermeyer, 2016).

Farmers achieve average yields of 30-40 t/ha, but ideally should be producing close to $70 \mathrm{t} /$ ha (Philips, 2017 and references therein). Forage chicory is a potentially valuable pasture component because it is a drought-tolerant, high yielding plant that can improve seasonal distribution of high quality herbage (Ditsch \& Sears, 2007; Perks, 2011). It is highly recommended to be planted in a lucerne or legume mixture. Chicory is known to contain protein levels ranging between 10 and $32 \%$ depending on the maturity of the plant, with the digestibility of chicory leaves ranging from $90-95 \%$ (Moraru et al., 2012). Chicory contains essential minerals such as $\mathrm{K}, \mathrm{Ca}, \mathrm{Mg}, \mathrm{S}, \mathrm{Zn}$ and $\mathrm{Na}$, which are required for adequate nutrition by animals (David \& Sears, 2007). Chicory fodder is rich in mineral elements, particularly $\mathrm{P}$, $\mathrm{K}, \mathrm{Ca}, \mathrm{Cu}, \mathrm{B}$, and $\mathrm{Zn}$ compared to Medicago sativa (alfalfa or lucerne), Trifolium (white clover) and Dactylis glomerata (cock's foot) (Moraru et al., 2012).

Chicory accumulated and removed higher concentrations of $\mathrm{K}$ and $\mathrm{N}$ than Zea mays (maize) and Brassica rapa (turnip) in a study conducted by Perks (2011), where it was reported that the chicory removed up to $530 \mathrm{~kg} / \mathrm{ha} \mathrm{K}$ and 365 $\mathrm{kg} /$ ha N. Considering the substantial amounts of elements that chicory can remove and redistribute, the species may hold potential to be used as a catch crop where there is irrigation with winery wastewater in vineyards or open land.

\section{Annual legumes}

Vigna unguiculata (Cowpea)

Cowpea is an annual legume largely produced by small scale farmers under dry land agricultural conditions (Agyeman et al., 2014). The species has many uses, with the seeds, young leaves and pods all being considered important, depending on its intended use. Cowpea is grown directly from seed in well-drained soil and may be intercropped with cereals such as pearl millet and sorghum (DAFF, 2011). It grows best during summer, has an affinity for high temperatures and displays drought tolerant properties due to its ability to utilize soil water efficiently (Agyeman et al., 2014). The crop is adaptable to a wide range of soils, however, sandy soils are preferred as this soil type is less restrictive on the root growth and development. Cowpea thrives in well-drained soils, with a $\mathrm{pH}$ ranging from 5.6-6.0 and can grow under rainfall ranging from 400-750 mm per annum (DAFF, 2011).

Cowpea is often employed in agricultural systems because it fixes atmospheric $\mathrm{N}$ and can be grown in $\mathrm{N}$-poor soils without additional fertilizer application (Bationo et al., 2002). Harvesting of the crop is dependent on when maturity is reached. Grain types have a short growth duration $(<100$ days), whereas those grown for forage usually have longer growth time, usually $>120$ days. The crop may be harvested by hand or a harvester and can be used as both vegetable and grain. It is considered a dual purpose crop as the green pods are used as vegetable and the remaining crop as livestock fodder. Local farmers supplement $25 \%$ of their annual income through the sale of cowpea fodder during the dry seasons. In terms of their cultivation, cowpea should be kept free of weeds during the early stages of growth and pests duly monitored, as insect pests are the major limiting factor in cowpea production (DAFF, 2011).

A pot experiment conducted by Silva et al. (2003) investigated the physiological response of cowpea to $\mathrm{NaCl}$ stress. In this particular study, responses of cowpea in nutrient solution was compared to cowpea in either (i) nutrient solution containing $75 \mathrm{mmol} / \mathrm{L} \mathrm{NaCl}$, (ii) nutrient solution containing $\mathrm{mmol} / \mathrm{L} \mathrm{NaCl}$ and $5 \mathrm{mmol} / \mathrm{L} \mathrm{CaCl}_{2}$ or (iii) nutrient solution containing $75 \mathrm{mmol} / \mathrm{L} \mathrm{NaCl}$ and $10 \mathrm{mmol} / \mathrm{L} \mathrm{CaCl}_{2}$. There was a $38 \%$ decrease in DMP in response to salinity. Sodium and chloride $(\mathrm{Cl})$ accumulation observed in the roots, stems, petioles and leaves was a result of the accumulated total inorganic solutes. In response to the $\mathrm{NaCl}$ stress, a $930 \%$ and $196 \%$ increase in root $\mathrm{Na}$ and $\mathrm{Cl}$ was observed, respectively, with increases in stem $\mathrm{Na}(880 \%), \mathrm{Cl}(576 \%)$ and $\mathrm{P}(25 \%)$ and a $19 \%$ decrease in $\mathrm{K}$. Given the substantial accumulation of $\mathrm{Na}$ in the roots and stems, cowpeas in a catch crop/cover crop system in a vineyard could potentially reduce the accumulation of $\mathrm{Na}$ added via irrigation with winery water. This species is also ideal for intercropping with cereals such as pearl millet and sorghum which require additional $\mathrm{N}$ inputs (Bationo et al., 2002; Medupe, 2010). 


\section{Dolichos lablab (Dolichos bean)}

Dolichos bean is a summer growing annual or short-lived perennial fodder legume (Murphy \& Colucci, 1999). It is used as a cover crop to improve soil fertility, and in the management of pests and diseases as it has shown to be resistant to most diseases and insects with only a few pests and diseases causing serious concern. Dolichos bean is adapted to a wide range of environmental and climatic conditions. It is drought tolerant and requires rainfall/ irrigation ranging from $10-20 \mathrm{~mm}$ for seed germination. This legume fodder crop does well in a range of soil types from sandy soil to heavy black clays. However, it does not tolerate water-logged soils and displays a $\mathrm{pH}$ tolerance of 5 to 7.5.

Dolichos bean is a forage legume and is used as feed for cattle, as it is highly palatable with a high protein content. The leaves of lablab contain $15-30 \%$ protein, has high levels of lysine with $55 \%$ digestibility making it an ideal feed for cattle, either grazed or dried and fed as hay (Shehu et al., 2001). Additionally, the protein is promptly degraded by the ruminant's gut, which aids in meeting the $\mathrm{N}$ requirements for microbial degradation of mediocre or low quality feed fibres (Shehu et al., 2001). The species has excellent biological $\mathrm{N}$-fixing abilities and was shown to fix atmospheric $\mathrm{N}$ to the extent of 120-200 kg/ha N under certain soil and climatic conditions (Valenzuela \& Smith, 2002).

\section{CONCLUSIONS}

Due to the current water scarcity in South Africa, using winery wastewater for irrigation of vineyards could be economically viable to producers and wineries. Irrigation with winery wastewater, which is rich in nutrients, can be beneficial to soil fertility as an alternative to conventional fertilizers. However, using winery wastewater for irrigation could have negative effects on the environment because of its high levels of $\mathrm{K}$ and $\mathrm{Na}$. Therefore, catch crops such as fodder producing annuals and perennials could be beneficial in vineyards and/or on open land to mitigate the negative effects of the wastewater. A selection of crops with nutrient interception abilities, preferably for salts, may be ideal for the removal of excess nutrients from the soil whilst reducing leaching and excess run off. The use of perennial grasses, annual winter growing grains and winter growing broadleaf $\mathrm{N}$-fixing annuals as winter cover crops in the South African wine industry has been extensively documented but their use as summer catch crops intercepting elements applied via wastewater irrigation has not yet been well researched. Therefore, different summer catch crops and winter cover crop combinations are currently being evaluated in a vineyard as well as on open land to determine which would be best at intercepting $\mathrm{K}, \mathrm{Na}$ and other nutrients applied via winery wastewater irrigation.

\section{LITERATURE CITED}

Abd El-Lattief, E.A., 2011. Growth and fodder yield of forage pearl millet in newly cultivated land as affected by date of planting and integrated use of mineral and organic fertilizers. Asian J. Crop Sci. 3, 35-42.

Agyeman, K., Berchie, J.N., Osei-Bonsu, I., Tetteh Nartey, E. \& Fordjour, J.K., 2014. Growth and yield performance of improved cowpea (Vigna Unguiculata L.) varieties in Ghana. Agri. Sci. 2, 44-52.
Albassam, B.A., 2001. Effect of nitrate nutrition on growth and nitrogen assimilation of pearl millet exposed to sodium chloride stress. J. Plant Nutr. $24,1325-1335$

Anon, 2015. "All about chicory". Farmer's Weekly. August 24. Available at www.farmersweekly.co.za/farm-basics/how-to-crop/all-about-chicory/

Anon, 2017. Chicory-commander, Barenbrug, South Africa. https://www. barenbrug.co.za/forage/products/chicory-commander.htm downloaded 30 November 2017.

Anwar, M., Patra, D.D. \& Singh, D.V., 1996. Influence of soil sodicity on growth, oil yield and nutrient accumulation in Vetiver (Vetiveria zizanioides). Ann. Arid Zone 35, 49-52.

Arienzo, M., Christen, E.W. \& Quayle, W.C., 2009. Phytotoxicity testing of winery wastewater for constructed wetland treatment. J. Hazard. Mat. $169,94-99$.

Aronsson, H., Hansen, E.M., Thomsen, K. I., Liu, J., Ogaard, A.F., Känkänen, H. \& Ulén, B., 2016. The ability of cover crops to reduce nitrogen and phosphorus losses from arable land in southern Scandinavia and Finland. J. Soil. Water. Conv. 71, 41-55

Aronsson, H., Ringselle, B., Andersson, L. \& Bergkvist, G.G., 2015 Combining mechanical control of couch grass (Elymus repens L.) with reduced tillage in early autumn and cover crops to decrease nitrogen and phosphorus leaching. Nutr. Cyc. Agro.102, 383-396.

Asfaw, K.G. \& Dano, F.I., 2011. Response of dry matter production of tef [Eragrostis tef (Zucc.) Trotter]: Accessions and varieties to $\mathrm{NaCl}$ salinity current research. J. Biol. Sci. 3, 300-307.

Assefa, K., Cannarozzi, G., Girma, D., Kamies, R.,Chanyalew,S., PlazaWathrich, S., Biasch, R., Rindisbacher, A., Rafudeen, S. \& Tadele, Z., 2015. Genetic diversity in tef [Eragrostis tef (Zucc.) Trotter]. Plant Sci. 6,177189.

Assefa, K., Yu, J.K., Zeid, M., Belay, G., Tefera, H. \& Sorrells, M.E., 2011. Breeding tef [Eragrostis tef (Zucc.) trotter]: conventional and molecular approaches. Plant Breed. 130, 1-9.

Bationo, A., Ntare, B.R., Tarawali, S.A. \& Tabo, R., 2002. Soil fertility management and cowpea production in the semiarid tropics. In: Fatokun C.A., Tarawali S.A., Singh B.B., Kormawa P.M., Tamo, M. (eds.) Challenges and opportunities for enhancing sustainable cow pea production. pp. $319-328$

Beletse, Y.G., 2004. Modelling the soil water and salt balance of planted pastures irrigated with sodium sulphate rich mine effluent. Thesis, University of Pretoria, Private Bag X20, 0028 Hatfield (Pretoria), South Africa.

Blümmel, M., Zerbini, E., Reddy, B.V.S., Hash, C.T., Bidinger, F. \& Ravi, D., 2003. Improving the production and utilization of sorghum and pear millet as livestock feed: methodological problems and possible solutions. Field Crops Res. 84, 123-142.

Conradie, W. J., 1994. Vineyard fertilisation. Proceedings of workshop on vineyard fertilisation. 30 September 1994. ARC Infruitec-Nietvoorbij, Private Bag X 5026, 7599, Stellenbosch, South Africa.

Conradie A., Sigge, G.O. \& Cloete, T.E., 2013. Influence of winemaking practices on the characteristics of winery wastewater and water usage of wineries. S. Afr. J. Enol. Vitic. 35, 10-19.

Cook, B.G., Pengelly, B.C., Brown, S.D., Donnelly, J.L., Eagles, D.A., Franco, M.A., Hanson, J., Mullen, B.F., Partridge, I.J., Peters, M. \& Schultze-Kraft, R., 2005. Tropical Forages: an interactive se-lection tool. [CD-ROM], CSIRO, DPI\&F (Qld), CIAT and ILRI, Brisbane, Australia. http://www.tropicalforages.info downloaded 24 July 2017.

Danh, L.D., Truong, P., Mammucari, R. \& Foster, N., 2009. Response surface method applied to supercritical carbon dioxide extraction of Vetiveria zizanioides essential oil. Chem. Eng. J. 155, 617-626. 
David D.C. \& Sears, B., 2007. Chicory: An alternative livestock forage. Agric. Nat. Res. 4, 190-191.

Davison, J., Laca, M. \& Creech, E., 2011. The potential for teff as an alternative forage crop for irrigated regions http://alfalfa.ucdavis. edu/+symposium/proceedings/2011/11-86.pdf downloaded 24 July 2017.

Department of Agriculture, Forestry and Fisheries (DAFF), 2011. Production guidelines for Cowpeas. http://www.arc.agric.za/arc-gci/Fact $\% 20$ Sheets $\% 20$ Library/Cowpea $\% 20$ - $\% 2$ Production $\% 20$ guidelines $\% 20$ for\%20cowpea.pdf downloaded 24 July 2017.

Department of Agriculture, Forestry and Fisheries, 2012. http://www.nda. agric.za/docs/Brochures/Bottlebrush.pdf downloaded 24 July 2017.

Department of Water Affairs, 2013. Revision of general authorizations in terms of Section 38 of the National Water Act, 1998 (Act No. 36 of 1998), No. 665. Government Gazette No. 36820, 6 September 2013. Department of Water Affairs, Pretoria, South Africa, 3-31.

Ditsch, D.C. \& Sears, B., 2007. Chicory an alternative livestock forage. AGR-190, University of Kentucky Cooperative Extension Service-College of Agriculture, Lexington, KY., USA. http://www.ansc.purdue.edu/SP/MG/ Documents/agr190.pdf downloaded 24 July 2017.

FAO, 2011. Grassland Index. A searchable catalogue of grass and forage legumes. FAO http://www.fao.org/ag/AGP/AGPC/doc/GBASE/Default. htm downloaded 27 September 2017.

Fourie, J.C., 2011. Soil management in the Breede River Valley wine grape region, South Africa. 3. Grapevine performance. S. Afr. J. Enol. Vitic. 31, 14-21.

Fourie, J.C., 2012. Soil management in the Breede River Valley wine grape region, South Africa. 4. Organic matter and macro-nutrient content of a medium textured soil. S. Afr. J. Enol. Vitic. 33, 105-114.

Fourie, J.C., Agenbag, G.A. \& Louw, P.J.E., 2007b. Cover crop management in a Sauvignon Blanc/Ramsey vineyard in the semi-arid Olifants River Valley, South Africa. 3. Effect of different cover crops and cover crop management practices on the organic matter and macro-nutrient contents of a sandy soil. S. Afr. J. Enol. Vitic. 28, 92-100.

Fourie, J.C., Louw, P.J.E. \& Agenbag, G.A., 2001. Effect of seeding date on the performance of grasses and broadleaf species evaluated for cover crop management in two wine grape regions of South Africa. S. Afr. J. Plant Soil $18,118-127$

Fourie, J.C., Louw, P.J.E. \& Agenbag, G.A., 2005. Cover crop management in a Sauvignon blanc/Ramsey vineyard in the semi-arid Olifants River Valley, South Africa. 1. Effect of management practices on selected grass and broadleaf species. S. Afr. J. Enol. Vitic. 26, 131-139.

Fourie, J.C., Louw, P.J.E. \& Agenbag, G.A., 2006. Cover crop management in a Chardonnay/99 Richter vineyard in the Coastal Wine Grape Region, South Africa. 2. Effect of different cover crops and cover crop management practices on grapevine performance. S. Afr. J. Enol. Vitic. 27, 178-186.

Fourie, J.C., Louw, P.J.E. \& Agenbag, G.A, 2007a. Cover crop management in a Sauvignon blanc/Ramsey vineyard in the semi-arid Olifants River Valley, South Africa. 2. Effect of different cover crops and cover crop management practices on grapevine performance. S. Afr. J. Enol. Vitic. 28, $81-91$

Fourie, J.C., Louw, P.J.E. \& Agenbag, GA., 2007c. Cover crop management in a Chardonnay/99 Richter vineyard in the Coastal Region, South Africa. 3. Effect of different cover crop and cover crop management practices on organic matter and macro-nutrient content of a medium textured soil. S. Afr.J. Enol. Vitic. 28, 61-68.

Fourie, J. C., Theron H. \& Ochse, C. H., 2015. Effect of irrigation with diluted winery wastewater on the performance of two grass cover crops in vineyards. S. Afr. J. Enol. Vitic. 36, 210-222.
Glabb T. \& Kullkig, B., 2008. Effect of mulch and tillage system on soil porosity under wheat (Triticum aestivum). Soil Till. Res. 99,169-178.

Grain SA, 2014, Conservation agriculture-Part 7. http:/www.grainsa.co.za/ conservation-agriculture:-part-7 downloaded 24 July 2017.

Harinarayana, G., Melkania, N.P., Reddy, B.V.S., Gupta, S.K., Rai, K.N. \& Kumar, P.S., 2005. Forage potential of sorghum and pearl millet. In: 7th International Conference on the Development of Dryland, ICARDA, Syria. pp. 292-321.

Houlbrooke, D., Laurenson, S. \& Carrick, S., 2011. Categorising the environmental risk from land application of liquid wastes based on soil properties. In: Categorising the environmental risk from land application of liquid wastes based on soil properties. Report prepared for Marlborough District Council. Agri. Res. Pp. 49

Kammermeyer, K. 2016. Forage chicory-Cichorium intybus. https://www. pennington.com/resources/agriculture/wildlife/articles/forage-chicorycichorium-intybus

Karpiscak, M.M., Gerba, C.P., Watt, P.M., Foster, K. \& Falabi, J.A.,1996. Multi-species plant systems for wastewater quality improvements and habitat enhancement. Water Sci. Techn. 33, 231-236.

Kassier S.B., 2002. Comparative responses of fodder and grain teff (Eragrostis tef (Zucc) Trotter). Thesis, University of Natal, 238 Mazisi Kunene Road, Glenwood, Durban, 4041, South Africa.

Kebede, T., 2012. Response of tef [Eragrostis tef (Zucc.) Trotter] cultivars to nitrogen and phosphorus fertiliser rates at Menzkeya District, North Shewa, Ethiopia. Thesis, University of Haramaya, P.O.Box 138, Dire Dawa, Ethiopia.

Ketterings, Q.M., Godwin, G., Kilcer, T. F., Barney, P., Hunter, M., Cherney, J. H. \& Beer, S., 2006. N, P, and K removal for brown midrib sorghum sudangrass in New York. Wh. Crop. Up. 16, 4-6.

Khan, M.A., Shaukat, S.S., Shahzad, A. \& Arif, H., 2012. Growth and yield responses of pearl millet (Pennisetum glaucum (L.) R. Br.) irrigated with treated effluent from waste stabilization ponds. Pak. J. Bot. 44, 905-910.

Krishnamurthy, E, Rachid Serraj, E., Kedar Nath Rai, E.C., Hash, T., Abdullah, J. \& Dakheel,. 2007. Identification of pearl millet [Pennisetum glaucum (L.) R. Br.] lines tolerant to soil salinity L. Euphytica 158,179-188.

Kristensen, H.L. \& Thorup-Kristensen, K., 2004. Root growth and nitrate uptake of three different catch crops in deep soil layers. Soil Sci. Soc. Am. J. 68, 529-537.

Laurenson, S., Bolan, N.S., Smith, E. \& McCarthy, M., 2012. Review: Use of recycled wastewater for irrigating grapevines. Aust. J. Grape Wine Res. $18,1-10$.

Laurenson, S. \& Houlbrooke, D., 2011. Winery wastewater irrigation The effect of sodium and potassium on soil structure. Report prepared for Marlborough District Council. Agri. Res. 22-28.

McClellan, T.A., Gaussoin, R.E., Shearman, R.C., Wortmann, C.S., Mamo, M., Horst, G.L. \& Marx, D.B., 2009. Nutrient and chemical properties of aging golf course putting greens as impacted by soil depth and mat development. Hort. Sci. 44, 452-458.

Medupe, M., 2010. Improving dry land maize (Zea mays) productivity through crop rotation with cowpeas (Vigna unguiculata). Thesis, University of Pretoria, Private Bag X20, 0028 Hatfield (Pretoria), South Africa.

Meisinger, J.J., Hargrove, W.L., Mikkelsen, R.L., Williams, J.R. \& Benson, W., 1991. Effects of cover crops on groundwater quality. In: Hargrove, W.L. (ed.). Cover crops for clean water. SWCS. Ankeny, IA. Mendes, I.C., A.K. Bandick, R.P. Dick, and P.J. Bottomley, pp. 57-68.

Moraru, N., Dragomir, N., Padeanu I. \& Ghiocel, C. 2012. Forage chicory. Res. J. Agric. Sci. 44, 125-128. 
Mosse, K.P.M., Patti, A.F., Christen, E.W. \& Cavagnaro, T.R., 2011 Review: Winery wastewater quality and treatment options in Australia. Aus. J. Grape Wine Res. 17, 111-121.

Mulidzi, A.R., 2001. Environmental impact of winery effluent in the Western and Northern Cape Provinces. Thesis, University of Pretoria, Private Bag X20, 0028 Hatfield (Pretoria), South Africa.

Mulidzi, A.R., Clarke, C.E. \& Myburgh, P.A., 2016. Effect of irrigation with diluted winery wastewater on cations and $\mathrm{pH}$ in four differently textured soils. S. Afr. J. Enol. Vitic. 37, 79-84.

Murphy, A.M. \& Colucci, P.E., 1999. A tropical forage solution to poor quality diets: a review of Lablab purpureus. Livestock Res.11, 112

Myburgh, P.A. \& Howell, C.L. 2014a. Effect of irrigation with augmented winery wastewater on soil chemical status. In: Myburgh, P.A. \& Howell, C.L. (eds). The impact of wastewater irrigation by wineries on soil, crop growth and product quality. Water Research Commission Report No. 1881/14. Private Bag X03, Gezina, South Africa, 0031.

Myburgh, P.A. \& Howell, C.L., 2014b. Assessing the ability of fodder beet (Beta vulgaris L. 'Brigadier') to absorb sodium from a soil irrigated with sodium-enriched water. S. Afr. J. Plant Soil 31, 113-115.

National Water Act, 1998 (Act 36 of 1998). Government Gazette 19182, Notice 1091 of 26 August 1998. Republic of South Africa (RSA).

Nemecek, T. \& Gaillard, G., 2010 Challenges in assessing the environmental impacts of crop production and horticulture. In: Sonesson, J.B. (ed.). Life cycle assessment and related approaches, Vol 194. Oxford. pp. 98-116.

Ngouajio, M. \& Mutch, D.R., 2004. Oilseed radish: a new cover crop for Michigan. Extension Bulletin E 2907, East Lansing Michigan State Univ.p.4.

Oleiwi, I.A.M, Faraj, A.H., Hasoun, S.N. \& Alhamza, J.S.A. 2015. Effect of soil salinity on growth of millet in lysimeter experiment. J. Agr. Vet. Sci. $8,1-8$.

Paz-Alberto, A. M. \& Sigua, G.C., 2013. Phytoremediation: A green technology to remove environmental pollutants. Am. J. Clim. Ch. 2, 71-86.

Peltonen-Sainio, P., Rajala, A.; Känkänen, H. \& Hakala, K., 2014. Improving farming systems in northern Europe. In: Sadras, V.O. \& Calderini, D.F. (eds.). Crop physiology: Applications for genetic improvement and agronomy. pp. 65-91

Perks, M.J. 2011. Can chicory be used to reduce nutrient loading on the effluent block in adding to the knowledge base for the nutrient manager. Occasional Report No. 24, Currie, C.L. Christensen, eds. Fertilizer and Line Research Centre, Palmerston North, New Zealand. http://flrc.massey.ac.nz publications.html. L.D. date accessed 13 June 2017.

Philips, L., 2017. Maximising chicory yields with optimal planting densities - crops - chicory. Farmer's Weekly, Volume 2017 Number 17034, Sep 2017, 48-50.

Ramatoulaye, F., Mady, C. \& Fallou, S., 2016. Production and use sorghum: A literature review. J. Nutr. Health Food Sci. 4, 1-4.

Sapkota, T.B., Askegaard, M., Lægdsmand, M. \& Olesen, J.E., 2011. Effects of catch crop type and root depth on nitrogen leaching and yield of spring barley. Field Crops Res. 125, 129-138.

SAWIS South African wine: Harvest report, 2017. Downloaded at http://vinpro.co.za/wp-content/uploads/2017/05/VinPro-SA-Wine-HarvestReport-2017_COMPLETE.pdf date accessed 13 June 2017.

Seyfu K., 1993. Tef (Eragrostis tef): breeding, genetic resources, agronomy, utilization and role in Ethiopian agriculture. Institute of Agricultural Research, Addis Ababa, Ethiopia.
Shehu, Y., Alhassan, W.S., Pal, U.L. \& Phillips, C.J.C., 2001. Yield and chemical composition responses of Lablab purpureus to nitrogen, phosphorus and potassium fertilisers. Tropical Grasslands 35, 180-185.

Sheridan, C.M., Glasser, D., Hildebrandt, D., Petersen, J. \& Rohwer, J., 2011. An annual and seasonal characterisation of winery effluent in South Africa. S. Afr. J. Enol. Vitic. 32, 1-8.

Silva, J.V., de Lacerda C.F., da Costa, P.H., Filho, J.E., Filho, E.G. \& Prisco, J.T., 2003. Physiological responses of $\mathrm{NaCl}$ stressed cowpea plants grown in nutrient solution supplemented with $\mathrm{CaCl}_{2}$. Braz. J. Plant Physiol. 15, 99-105.

Squires, V.R. \& Myers, L.F., 1970. Performance of warm season perennial grasses for irrigated pastures at Deniliquin, South-eastern Australia. Trop. Grass. 4, 153-161.

Stallknecht, G.F., Gilbertson, K.M. \& Eckhoff, J.L., 1993. Teff: Food crop for humans and animals. In: Janick, J. \& Simon, J.E. (eds.). New crops. Wiley, New York. pp. 231-234.

Strickland, R.W., 1973. Dry matter production, digestibility and mineral content of Eragrostis superba Peyr. and E. curvula (Schrad.) Nees. at Samford, South-eastern Queensland. Trop. Grasslands 7, 233-241.

Strochbach, B.J. 2000., Vegetation degradation trends in the northern Oshikoto region: I. The Hyphaene petersiana plains. Dinteria 26, 45-62.

Tesfamariam, T.H., Annandale, J.G., Steyn, J.M., Stirzaker, R.J. \& Mbakwe, I., 2013. Municipal sludge as source of nitrogen and phosphorus in perennial pasture Eragrostis curvula production: Agronomic benefits and environmental impacts. Water SA 39, 507-514.

Truong, P.N., 1994. Vetiver grass, its potential in the stabilisation and rehabilitation of degraded and saline lands. In: Squire, V.R. \& Ayoub, A.T. (eds.). Halophytes a resource for livestock and for rehabilitation of degraded land, Kluwer Academics Publisher, Netherlands. pp. 293-296.

Truong, P., Gordon, I. \& Armstrong, F., 2002. Vetiver grass for saline land rehabilitation under tropical and Mediterranean climate. Eighth National Conference productive use of saline lands. Perth, Australia.

Truong, P., Truong, S. \& Smeal, C., 2003. Application of the vetiver system in computer modelling for industrial wastewater disposal. Proc. Third International Vetiver Conference, Guangzhou, China, October 2003.

Valenzuela, H. \& Smith, J., 2002. Sustainable Agriculture: Green Manure Crops. Cooperative Extension Service, University of Hawaii, Hawaii. http:// www.ctahr.hawaii.edu/ sustaining.

Van Schoor, L.H., 2000. Management options to minimise negative environmental impacts at wine cellars. Wineland, July, 11.

Van Schoor, L.H., 2001. A formula for the quantification and prioritization of negative environmental impacts in the wine industry. Wineland May, 100-102.

Van Schoor, L.H., 2005. Guidelines for the management of wastewater and solid waste at existing wineries.

http://www.ipw.co.za/Winetech $\% 20$ Wastewater\%20guidelines $\% 20$ document $\% 20$ April $\% 2005 \% 20$ English.pdf date accessed 29/10/2016.

Van Schoor, L. \& Rossouw, J., 2004. Winery wastewater and solid waste management. Wineland March, 82-83.

Wang , H., Inukai, Y. \& Yamauchi, A., 2006. Root development and nutrient uptake. Crit. Rev. Plant Sci. 25, 279-301.

Wiersema J.H. \& Dahlberg J. 2007. The Nomenclature of Sorghum bicolor (L.) Moench (Gramineae). Taxon. 56, 941-946.

White, C.M. \& Weil, R.R., 2011. Forage radish cover crops increase soil test phosphorus surrounding radish taproot holes. Soil Sci. Soc. Am. J. 75, 121-130. 
Williams, S.M. \& Weil, R.R., 2004. Crop cover root channels may alleviate soil compaction effects on soybean crop. Soil Sci. Soc. Am. J. 68, 14031409.

Zingelwa, N., 2004. Element uptake by macrophytes during the treatment of winery wastewater using constructed wetlands. Thesis, University of the Western Cape, Private Bag X17, 7535 Bellville, South Africa.
Zingelwa, N.S. \& Wooldridge, J. 2009. Tolerance of macrophytes and grasses to sodium and chemical oxygen demand in winery wastewater. S. Afr. J. Enol. Vitic. 30, 117-123.

Zingelwa, N. \& Wooldridge, J., 2010. Comparison between Kikuyu and Vetiver grasses used for the disposal of winery wastewater. Wynboer Technical Yearbook, 38-39. 